Creative commons User License: CC BY-NC-ND

Abstracted by: EBSCOhost, Electronic Journals Service (EJS), Google Scholar, Journal Seek, Scientific Commons,

Food and Agricultural Organization (FAO), CABI and Scopus
Journal of Agricultural Extension

Vol. 22 (1) February, 2018

ISSN(e): 24086851; ISSN(Print); 1119944X

http://journal.aesonnigeria.org

http://www.ajol.info/index.php/jae

Email: editorinchief@aesonnigeria.org

\title{
Price Variation of Tomatoes and Ginger in Giwa Market, Kaduna State, Nigeria
} https://dx.doi.org/10.4314/jae.v22i1.9

\author{
Mani, Jamila Rabe \\ National Agricultural Extension Research and Liaison Services (NAERLS) \\ Ahmadu Bello University, Zaria \\ Email: jamilarabemani3@gmail.com, Phone: +2348035968359

\section{Hudu, Muhammad I.} \\ National Agricultural Extension Research and Liaison Services (NAERLS) \\ Ahmadu Bello University, Zaria \\ Email: inrhud1@gmail.com, Phone: +2347030131637 \\ Ali, Abdurrahman \\ National Agricultural Extension Research and Liaison Services (NAERLS) \\ Ahmadu Bello University, Zaria \\ Email: alimabdul@yahoo.com, Phone: +2347062228525
}

\begin{abstract}
This study analysed price of tomatoes and ginger in Giwa market, Kaduna State to identify seasonal price patterns and their expected changes over time. The analytical approach in this study was based on the price multiplicative model. The study based preliminary on secondary data collected from NAERLS weekly commodity prices during period 2011-2015. The study found that the Grand Seasonal Index (GSI) showed a deviation from hundred, suggesting seasonality exists in the market for both commodities. The trend and variability of the seasonal index were also calculated and it revealed that the grand seasonal indexes of the commodities in the market were highly variable and this indicates minimal incentives for the rural farmers and marketers of ginger and tomato. Further the result indicated that tomato has the highest volatility than ginger in the market. Declining trends were obtained for majority of the months in both tomato and ginger marketing an indication of principle of supply and demand. The feasibility for storage were $20.71 \%$ and $21.44 \%$ for tomato and ginger respectively, implying that the producers/marketers of both tomato and ginger will make highest returns if they stored and sold to other (urban/international) markets during periods of high prices rather than selling at the rural market during harvests. Consequently, marketing of ginger and tomato in terms of better prices in these markets is less favorable. Hence recommendation of the implementation of seasonable price stability by the government. In addition, there is need to boost production, activate value chain, collecting and disseminating market information.
\end{abstract}

Keywords: Price variations, grand seasonal index, tomato, ginger 
Creative commons User License: CC BY-NC-ND

Abstracted by: EBSCOhost, Electronic Journals Service (EJS),

Google Scholar, Journal Seek, Scientific Commons,

Food and Agricultural Organization (FAO), CABI and Scopus
Journal of Agricultural Extension

Vol. 22 (1) February, 2018

ISSN(e): 24086851; ISSN(Print); 1119944X

http://journal.aesonnigeria.org

http://www.ajol.info/index.php/jae

Email: editorinchief@aesonnigeria.org

\section{Introduction}

Vegetable production is an integral part of the Nigerian agricultural sector. Vegetables are produced in different agro-ecological zones particularly by small scale farmers. Thus, its production has been on-going for decades, providing employment and income for the increasing population (Busari et al., 2012). Vegetable crops give 5-10 times more yield per unit area than cereals, they are quick growing and short duration (Shende and Meshram, 2015). The short duration nature of vegetables offers scope for raising two or more crops a year and for fitting effectively in different cropping system.

Tomato (Lycopersicon esculenta) is the second most important vegetable crop after potato in the world because it contains large amounts of vitamin C, providing 40 percent of the daily value (DV) (Bhowmik, et al., 2012). Additionally, it also contains 15 percent DV of vitamin A, 8 percent DV of potassium, and 7 percent of the recommended dietary allowance (RDA) of iron for women and 10 percent RDA for men. It can be grown in many areas of Nigeria and opportunities for increasing its production are considerable. Both wet and dry season cropping contributes immensely to the national requirement but the bulk of the production is from dry season cropping particularly under irrigation in the northern states and near perennial river banks in the south (Anon, 1989 in Aminu, 2004). Nigeria ranks as the second highest producer of tomato in Africa, the country is $13^{\text {th }}$ in the world (FAO, 2011), but Nigeria is not on the lists of official exporting countries of tomato or tomato products. The demand for tomato is currently estimated at about 2.3 million metric tons per annum, while only about 1.8 million metric tons is locally produced in the country (Central Bank of Nigeria, 2014). The report further stated that about $\$ 16$ billion is spent annually on the importation of tomato paste into the country.

Ginger (Zingiber officinale) is an important and widely grown flowering plant whose rhizome is commonly used as a spice or a folk medicine. Ginger originated in the tropical rainforest in Southern Asia, produced in different parts of Nigeria, while Kaduna State remains the largest producer of "taffin Giwa and yatsun Biri" varieties of ginger (NdaNmadu and Marcus, 2013). The country is one of the largest producers and exporters of ginger in the world especially the split dried ginger (Folorunso and Adeniga, 2013). Among other vegetables in Nigeria, it is the only vegetable that is grown on commercial scale for export; it is mainly exported in split dried form, while exports of fresh ginger are negligible (Eze and Agbo, 2011)

A well-developed marketing system is expected to complement production effort towards the realization of its desirable goal through the provision of time, space, possession and form. Adeoye et al. (2009) indicated that as a perishable crop, tomato has frequent variations in price even on a daily basis. On the other hand, though, ginger as an export commodity has recorded an annual price growth of 39\% between 2008 and 2012 (Ewuziem, et al., 2015), and that the unit price for Nigeria ginger remains higher than the world average. Price provides the incentive to both producers and consumers; higher prices encourage more production by the producers but less consumption by the consumers, while low prices discourage 
Creative commons User License: CC BY-NC-ND

Abstracted by: EBSCOhost, Electronic Journals Service (EJS),

Google Scholar, Journal Seek, Scientific Commons,

Food and Agricultural Organization (FAO), CABI and Scopus
Journal of Agricultural Extension

Vol. 22 (1) February, 2018

ISSN(e): 24086851; ISSN(Print); 1119944X

http://journal.aesonnigeria.org

http://www.ajol.info/index.php/iae

Email: editorinchief@aesonnigeria.org

production by the producers and encourage consumption by the consumers. These mechanisms push the price to balance the forces of demand and supply providing the most efficient economic outcome possible. Therefore, tomato and ginger marketing comprises of a complex and diverse array of independent markets facing different supply conditions, marketing needs and demand trends. Hence, understanding price seasonality and the economic factors behind it aid the study of demand and supply relationships within the vegetable market. Given that vegetable prices tend to be more volatile than those for staple commodities.

Uncertainty in crop prices makes it difficult for farmers in Nigeria to be confident, that they will obtain a sufficient return from the sale of the additional harvest. This is because the storage process is technically difficult and expensive, agricultural prices are therefore subject to strong seasonal variations. This is alleviated by fluctuations of provision of information and market news services that assist producers in organizing supply and enabling farmers to re-rout goods to other markets which suffer from a shortage of supply or high-demand markets. There is therefore a need to understand the pattern of price variations, price trends, monthly seasonal indices and their deviations to establish policies that help stabilize food prices. The main objective of the study was to analyze the trend in prices of tomato and ginger, and to identify seasonal price variations in Giwa market. Specifically, the paper addresses the following objectives:

- analyze the seasonal price variation of tomato and ginger prices in Giwa market; and

- identify potential policies for price stabilization.

\section{Methodology}

\section{The Study Area}

Giwa local government area of Kaduna State has an area of about 2,066 km² and lies between latitude $11^{\circ} 00^{\prime}-1130 \mathrm{~N}$ and longitude $7^{0} 00^{\prime}-7^{0} 45^{\prime} \mathrm{E}$ of the equator found in the northern guinea and south tip of the savannah. The local government had an estimated population of about 292,384 (NPC, 2006), and it was estimated to increase to about 413,456 by 2017 based on the National Population Commission (NPC) annual growth rate of $3.2 \%$. The average rainfall is about $1100 \mathrm{~mm}$ spanning from late April to late October, whereas mean temperature varies from $27-35^{0}$ depending on the season (Ajala et al., 2007). The people of Giwa Local Government Area are mainly peasant farmers, while some are engaged in livestock production.

\section{Source of Data}

Secondary time series commodity price data (2011-2015) was obtained from National Agricultural Extension Research and Liaison Services (NAERLS), Ahmadu Bello University $(\mathrm{ABU})$, Zaria. This contained weekly retail price of fresh tomato and dried ginger from the selected market. 
Creative commons User License: CC BY-NC-ND

Abstracted by: EBSCOhost, Electronic Journals Service (EJS),

Google Scholar, Journal Seek, Scientific Commons,

Food and Agricultural Organization (FAO), CABI and Scopus
Journal of Agricultural Extension

Vol. 22 (1) February, 2018

ISSN(e): 24086851; ISSN(Print); 1119944X

http://journal.aesonnigeria.org

http://www.aiol.info/index.php/iae

Email: editorinchief@aesonnigeria.org

\section{Analytical Techniques}

The nature of the data available and the objectives of the study determined the choice of analytical tools. Data were analysed using descriptive statistics, price multiplicative model for time series decomposition. Seasonality analysis, gross storage returns and volatility analysis were also used to achieve the stated objectives.

\section{Multiplicative model for time-series decomposition}

The classical time series model consists of four components, the trend component, cyclical component, seasonal component and the random component. These can be additive or multiplicative. To test for seasonality, the multiplicative hypothesis for time series decomposition was employed to achieve the stated objectives. Following Maddala and Kim (1998), the most common approach is given as;

$\mathrm{P}=\mathrm{T} \times \mathrm{C} \times \mathrm{S} \times \mathrm{E}$

Where $\mathrm{P}=$ Price series

$\mathrm{T}=$ Trend component

$\mathrm{C}=$ Cyclical component

$\mathrm{S}=$ Seasonal component

$\mathrm{E}$ $=$

Decomposing a time series allows for emphasis to be only on the seasonal component, while overlooking the influence of production cycles, inflation and other random events. Seasonality is defined as regular pattern of price changes occurring within a year at given time points, with similar intensity in the same season, as a result of uneven demand, production and marketing.

\section{Seasonality analysis}

Seasonality analysis is a function of the seasonal index (SI) and the grand seasonal index (GSI). However, the first step in calculating the SI and GSI is the moving average (MA) and Centered moving average (CMA), CMA is given as follows;

$\mathrm{CMA}^{12}=\frac{\left[\sum_{i=t-6}^{i=t+5} P_{i}+\sum_{i=t+6}^{i=t-5} P_{i}\right]}{24}$

Where $\mathrm{CMA}=$ centered moving average, $\mathrm{P}=$ nominal price, $\mathrm{t}=$ time period.

The CMA completely smoothens out the irregular and the random components, and then centering the time series. The seasonal index is calculated as the ratio of the average value in a month to the overall annual average value, multiplied by hundred;

$\mathrm{SI}=\frac{P_{i}}{C M A^{12}} X 10$

The GSI further eliminates the random component in the SI, while summarizing the typical seasonal behavior of a time series. The GSI for an individual month is the 
Creative commons User License: CC BY-NC-ND

Abstracted by: EBSCOhost, Electronic Journals Service (EJS),

Google Scholar, Journal Seek, Scientific Commons,

Food and Agricultural Organization (FAO), CABI and Scopus
Journal of Agricultural Extension

Vol. 22 (1) February, 2018

ISSN(e): 24086851; ISSN(Print); 1119944X

http://journal.aesonnigeria.org

http://www.aiol.info/index.php/iae

Email: editorinchief@aesonnigeria.org

mean of the same month's Seasonal Index ( $\mathrm{SI})$ for all the years included in the moving average time series, then adjusted to sum up to 1200 with a monthly average of 100 . The recommended procedure for this is to multiply each month's GSI by a correction factor so that the adjusted total comes to 1200 as required and is thus given as;

$\mathrm{GSI}=\overline{S I} X \frac{1200}{\sum \overline{S I}_{i}}$

\section{Test for Price Seasonality}

Price seasonality is the statistically significant deviation of any GSI from the average value of 100 . Examining Standard Deviation (SD) in addition to each GSI value is important to indicate how reliable a given GSI value is. A typical pattern found in agricultural price data is that standard deviations and GSI values during the harvest seasons are both low, while they each tend to be high during the pre-harvest season. These patterns indicate that prices reliably reach seasonal low during one or two months of the harvest, then rise over the course of the year prior to the next harvest, but that the exact timing and level of the seasonal high is less predictable than the timing and level of the seasonal low. As a rule of thumb any grand seasonal index plus one standard deviation less than or equal 100 is said to be robust seasonal low and any grand seasonal index minus one standard deviation greater or equal 100 is said to be robust seasonal high (Mathenge and Tschirley, 2006). The null hypothesis $\left(\mathrm{H}_{0}\right)$ is that price seasonality is not present, implying that the GSI is 100. The alternative hypothesis $\left(\mathrm{H}_{1}\right)$ is that the GSI does not equal 100.

\section{Gross Storage Returns}

According to Trotter (1992) in Aminu (2004) GSR can be estimated from GSI, because the GSI is a measure of average change in the seasonal components of prices. The GSR can be calculated by computing the percentage increase from seasonal price low to seasonal price high of GSI. The computation is given as follows;

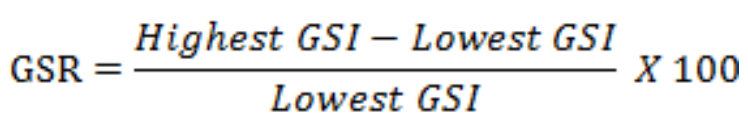

\section{Trend of the GSI and testing for its significance}

Examining trends in the GSI and testing for their significance gives an idea of whether price seasonality is increasing or decreasing over time. Each calendar month's SI series can be regressed on an annual time variable representing the number of years in the data set. The null hypothesis is that no trend exists and that $\beta$ $=0$. The regression equation is

$$
\mathrm{SI}_{\mathrm{t}}=\alpha+\beta \text { (seasons) }+\varepsilon_{\mathrm{t}}
$$


Creative commons User License: CC BY-NC-ND

Abstracted by: EBSCOhost, Electronic Journals Service (EJS),

Google Scholar, Journal Seek, Scientific Commons,

Food and Agricultural Organization (FAO), CABI and Scopus
Journal of Agricultural Extension

Vol. 22 (1) February, 2018

ISSN(e): 24086851; ISSN(Print); 1119944X

http://journal.aesonnigeria.org

http://www.ajol.info/index.php/iae

Email: editorinchief@aesonnigeria.org

Where, $\mathrm{SI}_{\mathrm{t}}$ is the set of the entire Sls for a calendar month; $\alpha$, the intercept term; $\beta$, the trend coefficient; seasons is season 1 to the maximum number of seasons in the data set and $\varepsilon_{\mathrm{t}}$, the error term.

\section{Results and Discussion}

\section{Price Characteristics of Tomatoes and Ginger}

The time series price data (nominal weekly prices) was recorded in Naira per thirtykilogram basket ( $\mathrm{A} / 30 \mathrm{~kg}$ basket) for fresh tomato and Naira per fifty-kilogram bag $(A / 50 \mathrm{~kg}$ bag) of dried ginger. The price variables used in the analyses is shown in Table I. The average price of fresh tomato in Giwa market of Kaduna State was N2814.37/30kg basket, also, the average price of dried Ginger was $110105.50 / 50 \mathrm{~kg}$ bag. The standard deviations of 2458.008 and 3820.4 in prices of fresh tomato and dried Ginger respectively, indicates that, changes in both prices assume similar patterns during the study period. In addition, the coefficient of variability in price of fresh tomato in the market was $87.34 \%$. The high variation was because of the higher price variations of fresh tomato in the market between the harvest and the lean periods. For dried Ginger, it stood at $37.81 \%$, this shows that, dried Ginger exhibited lower price variation than fresh tomato in the market.

Table 1: Price characteristics used in the model.

\begin{tabular}{lcc}
\hline parameters & Fresh tomato price (A/30kgbasket) & Dried ginger price (A/50kg bag) \\
\hline Mean & 2814.375 & 10105.5 \\
Median & 2050 & 9062.5 \\
Minimum & 700 & 4917.333 \\
Maximum & 15125 & 18750 \\
Std. Deviation & 2458.008 & 3820.4 \\
Co.Variation & 87.33763 & 37.80517 \\
Skewness & 3.124169 & 0.475964 \\
Kurtosis & 12.26331 & -1.21336 \\
\hline
\end{tabular}


Creative commons User License: CC BY-NC-ND

Abstracted by: EBSCOhost, Electronic Journals Service (EJS),

Google Scholar, Journal Seek, Scientific Commons,

Food and Agricultural Organization (FAO), CABI and Scopus
Journal of Agricultural Extension

Vol. 22 (1) February, 2018

ISSN(e): 24086851; ISSN(Print); 1119944X

http://journal.aesonnigeria.org

http://www.ajol.info/index.php/jae

Email: editorinchief@aesonnigeria.org

A 12-month centred moving average (CMA) was applied to this data set, such that each new data point represents a 12-month mean centred on an individual month (Figures 1 and 2). The effect of this procedure is to isolate the seasonal component of price changes from trend and cyclical components. Thus, removing shorter-term fluctuations in the series caused by the random and price seasonality factors, which then allows one to concentrate on cycles and trends (Goetz and Weber, 1986). Since each CMA is an entire season in length, it gives the seasonal pattern of the commodity. The seasonal pattern is the result of storage needed to bridge a discontinuous flow of supply with a continuous demand for a commodity over an annual cycle. While the overall direction of the plot was summarized with the trend equation given in a straight line (Figures 1 and 2).

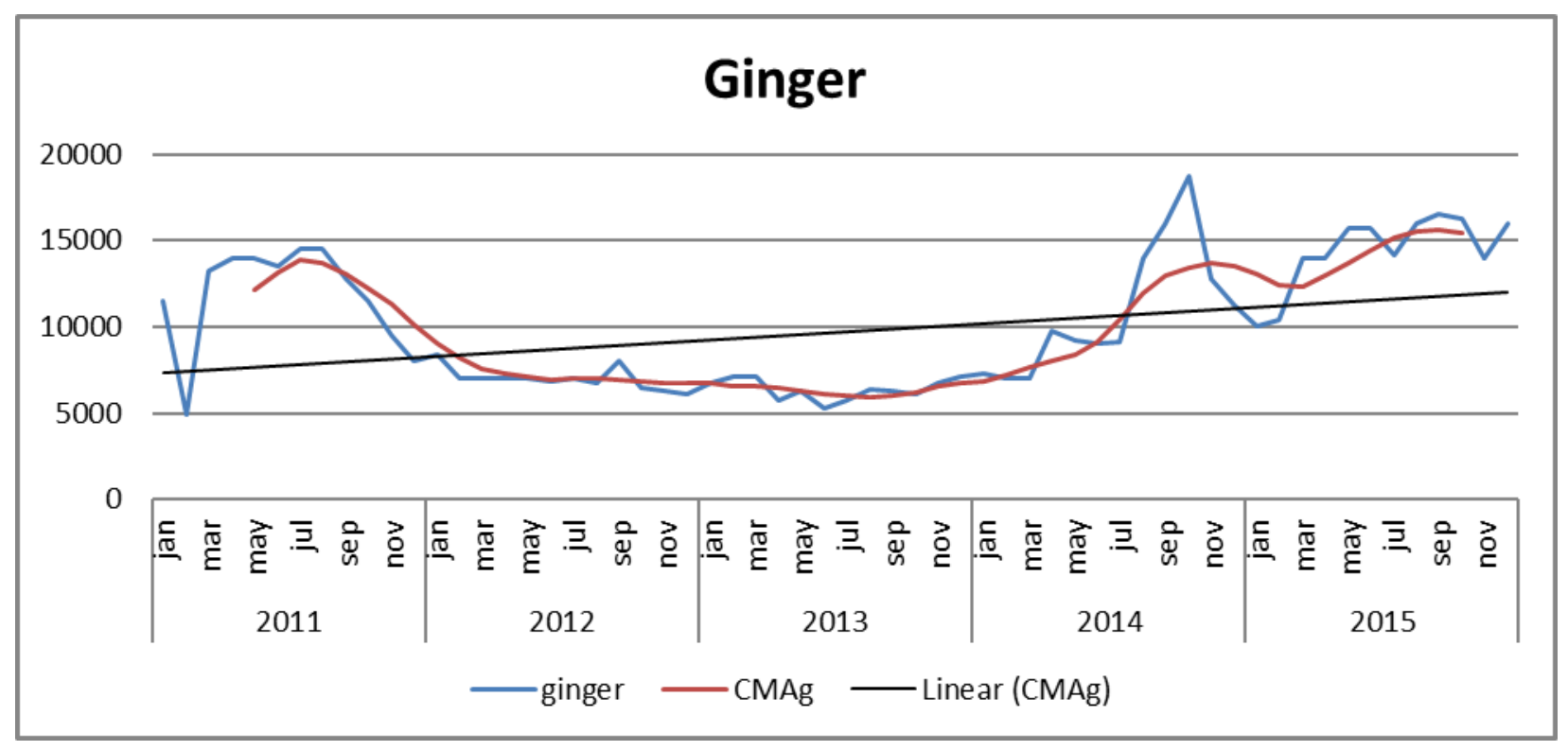

Figure 1: price and moving average of Tomato in Giwa Market 
Creative commons User License: CC BY-NC-ND

Abstracted by: EBSCOhost, Electronic Journals Service (EJS), Google Scholar, Journal Seek, Scientific Commons,

Food and Agricultural Organization (FAO), CABI and Scopus
Journal of Agricultural Extension

Vol. 22 (1) February, 2018

ISSN(e): 24086851; ISSN(Print); 1119944X

http://journal.aesonnigeria.org

http://www.ajol.info/index.php/jae

Email: editorinchief@aesonnigeria.org

\section{Tomato}

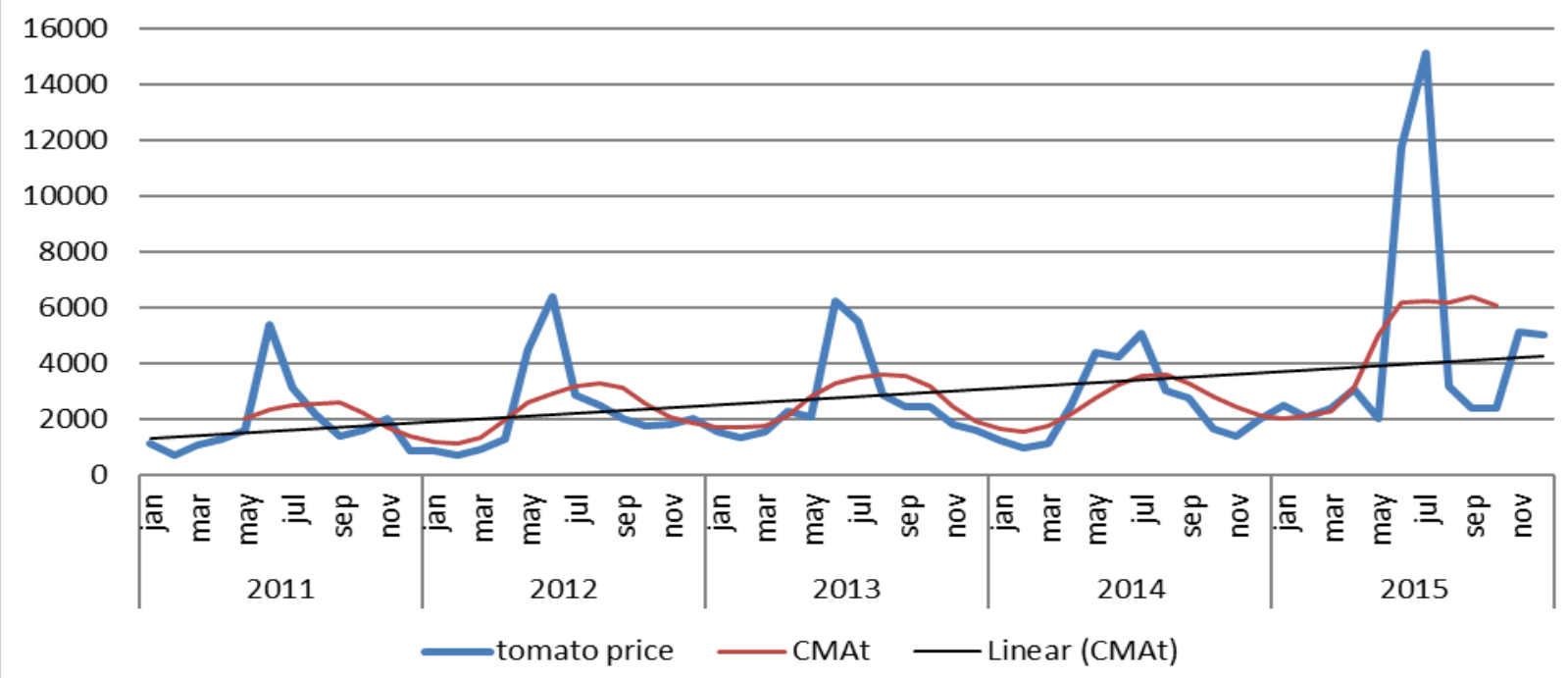

Figure 2: Price and moving average of Ginger in Giwa Market

\section{Price Variability Over Seasons}

Seasonality is the statistical variation reflecting the average amount by which prices during any given month deviates from the average value of 100 . Results of the analysis of seasonal variations of tomatoes and ginger in Giwa market are presented in Tables II and III respectively. The result in Table II showed that the values of the GSI deviates from 100 which is an indication that seasonality exists, consequently the null hypothesis of no significant variation in the price of tomato in Giwa market is rejected. Further the highest GSI were observed in the months of June, July and September, while October recorded the lowest GSI in the market. Monthly price variations are related to harvest period and/or the economic theory of supply and demand. The pronounced seasonal variation is because of the irrigated nature of tomato production in Nigeria and the resultant effect is low prices of tomato at harvest and high prices during rainy seasons especially in the month of September. Consequently, this has implications on income and food security, and those producers and traders faced enormous risks in production and marketing of tomato. This agrees with the report of Aminu (2006) who avers that onion farmers are faced with high risk in the production and marketing of onions in Jigawa State.

At the same time, Table II further shows that the values of the GSI deviates from 100 which is an indication that seasonality exists, hence the null hypothesis of no significant variation in the price of dried ginger in Giwa market is rejected. Highest GSI were obtained in the months of October, May and September, whereas December recorded the lowest GSI in the market. The monthly price variations indicated that prices reliably reach seasonal low one or two months after harvest. Then rise over the course of the year prior to the next harvest. This is in accordance with El-Hori and Idris (2011) in their study of temporal price analysis of wheat, faba bean dates and garlic crops in the Northern State, Sudan. 
Creative commons User License: CC BY-NC-ND

Abstracted by: EBSCOhost, Electronic Journals Service (EJS),

Google Scholar, Journal Seek, Scientific Commons,

Food and Agricultural Organization (FAO), CABI and Scopus
Journal of Agricultural Extension

Vol. 22 (1) February, 2018

ISSN(e): 24086851; ISSN(Print); 1119944X

http://journal.aesonnigeria.org

http://www.ajol.info/index.php/jae

Email: editorinchief@aesonnigeria.org

The variability of the GSI also means that there are opportunities in time and space for farmers and traders to store tomato and ginger and benefit from high prices, that is, it is important to consider GSR. Tomato is harvested twice a year while demand remains constant throughout. As a perishable crop, the techniques of storing fresh tomato longer than three days are not yet available or expensive to farmers and traders. On the other hand, though, ginger can be properly dried and stored for up to a year, though fresh ginger storage facilities are still not yet available to farmers. From the Tables, the degree of variability of the GSI for the commodities is given as GSI+SE and GSI-SE. Notably, this shows that tomato and ginger prices are erratic and unpredictable, nonetheless this is more pronounced in tomato than in ginger. It can then be deduced that performance of the market has not lived up to overcome vigorous price variations. That is, market news services to spread market information to market participants concerning market condition, quantities sold in each market and the prevailing day-by-day prices that will enable farmers to take the rational decisions regarding the timing and place of sales of produce has not been readily available to farmers.

The standard deviation measures the divergence of the monthly from the average index, an indication of seasonal pattern consistency. The GSI indicated that the trend in seasonal prices is pronounced, but not stable. Figures 3 and 4 graphically depict the average of the seasonal indices (GSI) for tomato and ginger that was quantitatively analysed. The lines over and under GSI represent GSI+SE and GSISE respectively, indicating that fluctuations are erratic and unpredictable. This agrees with the findings of Adenegan and Adeoye (2011) whom conducted a price analysis of tomato in rural and urban retail markets of Oyo State, Nigeria. They found the prices of tomato to be unstable in the study area.

Table 2: Seasonal price variation of tomato in Giwa Market.

\begin{tabular}{lccccccccccccc}
\hline Month & Jan & Feb & March & April & May & June & July & August & Sept. & Oct. & Nov. & Dec. \\
\hline Mean SI & 89.67 & 74.72 & 81.83 & 95.96 & 111.25 & 182.65 & 158.43 & 72.77 & 136.5 & 61.38 & 73.27 & 95.39 \\
GSI & 44.21 & 36.84 & 40.35 & 47.31 & 54.85 & 90.05 & 78.11 & 35.88 & 68.98 & 30.26 & 36.12 & 47.03 \\
GSI+ & 56.21 & 44.96 & 49.13 & 58.02 & 83.99 & 106.20 & 106.18 & 42.44 & 40.08 & 37.72 & 43.69 & 53.84 \\
SI & & & & & & & & & & & & & \\
GSI-SE & 32.21 & 28.72 & 31.56 & 36.61 & 25.71 & 73.91 & 50.04 & 29.32 & - & 22.81 & 28.56 & 40.23 \\
$\begin{array}{l}\text { Trend } \\
\text { coeff. }\end{array}$ & 1.65 & -34.17 & -47.93 & -54.67 & -60.26 & -9.73 & -54.83 & -161.36 & 10.85 & -214.50 & -223.49 & -222.24 \\
\hline
\end{tabular}


Creative commons User License: CC BY-NC-ND

Abstracted by: EBSCOhost, Electronic Journals Service (EJS),

Google Scholar, Journal Seek, Scientific Commons,

Food and Agricultural Organization (FAO), CABI and Scopus
Journal of Agricultural Extension

Vol. 22 (1) February, 2018

ISSN(e): 24086851; ISSN(Print); 1119944X

http://journal.aesonnigeria.org

http://www.ajol.info/index.php/jae

Email: editorinchief@aesonnigeria.org

Table 3: Seasonal Price Variationof Ginger in Giwa Market.

\begin{tabular}{|c|c|c|c|c|c|c|c|c|c|c|c|c|}
\hline Month & Jan & Feb & March & April & May & June & July & August & Sept. & Oct. & Nov. & Dec. \\
\hline mean=SI & 94.34 & 93.59 & 101.48 & 103.54 & 107.89 & 98.90 & 96.05 & 105.76 & 109.03 & 106.14 & 93.41 & 89.78 \\
\hline GSI & 94.34 & 93.60 & 101.49 & 103.56 & 107.89 & 98.91 & 96.07 & 105.77 & 109.04 & 106.14 & 93.42 & 89.79 \\
\hline GSI+SE & 100.92 & 99.38 & 107.34 & 110.55 & 111.64 & 102.75 & 98.90 & 109.27 & 113.58 & 114.67 & 97.45 & 95.79 \\
\hline GSI-SE & 87.76 & 87.83 & 95.63 & 96.54 & 104.15 & 95.08 & 93.21 & 102.26 & 104.51 & 97.62 & 89.38 & 83.78 \\
\hline $\begin{array}{l}\text { Trend- } \\
\text { Coeff }\end{array}$ & -5.68 & -6.41 & 1.48 & 3.54 & 7.89 & -1.09 & -3.94 & 5.77 & 9.05 & 6.16 & -6.57 & 10.19 \\
\hline
\end{tabular}

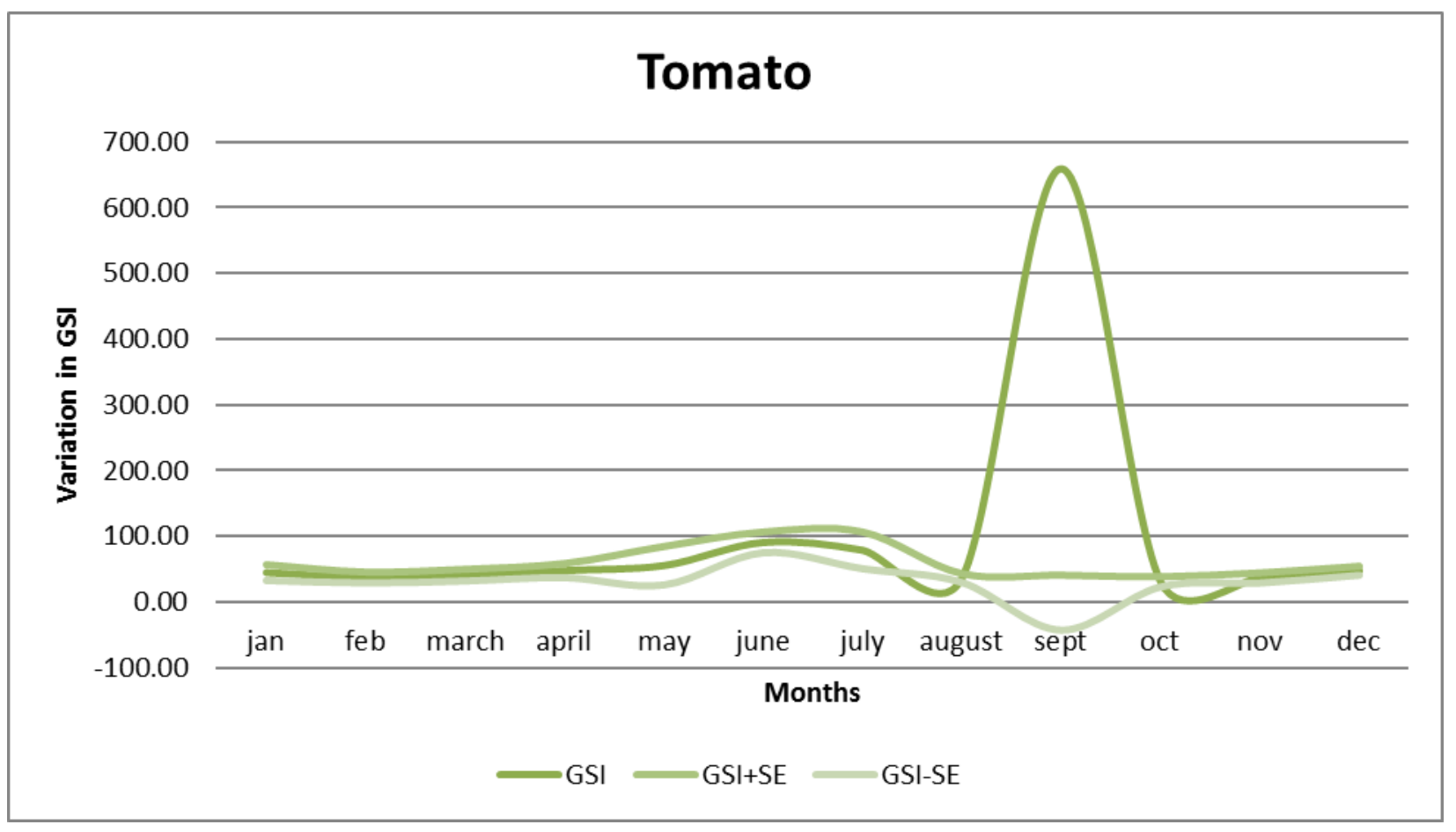

Figure 3: movement of grand seasonal index of Tomato in Giwa Market. 
Creative commons User License: CC BY-NC-ND

Abstracted by: EBSCOhost, Electronic Journals Service (EJS),

Google Scholar, Journal Seek, Scientific Commons,

Food and Agricultural Organization (FAO), CABI and Scopus
Journal of Agricultural Extension

Vol. 22 (1) February, 2018

ISSN(e): 24086851; ISSN(Print); $1119944 X$

http://journal.aesonnigeria.org

http://www.ajol.info/index.php/jae

Email: editorinchief@aesonnigeria.org

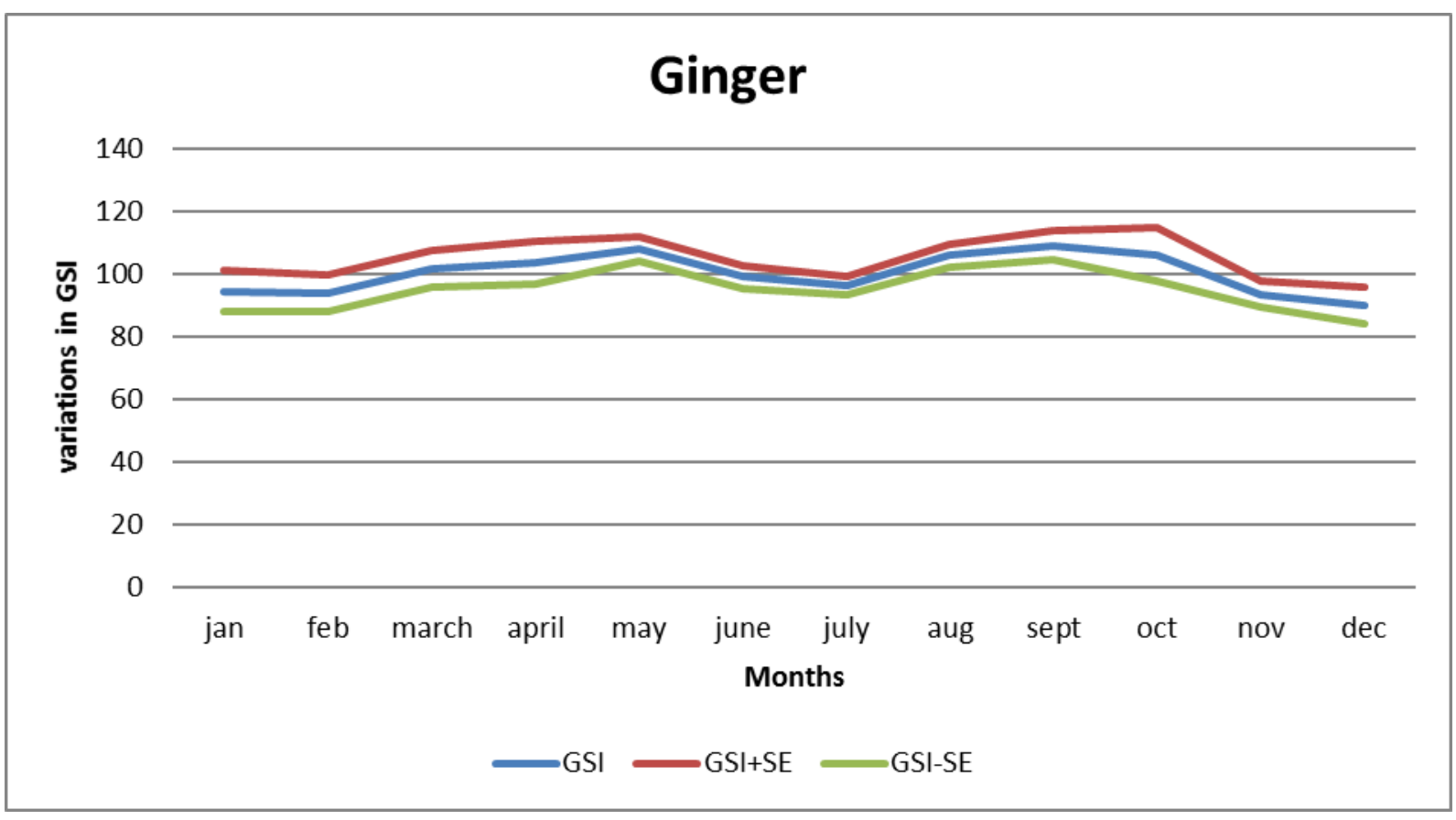

Figure 4: Movement of grand seasonal index of Ginger in Giwa Market.

\section{Trend in Grand Seasonal Index (GSI)}

The trend of the GSI were estimated by regressing each of the calendar month's SI on a time variable. The trend coefficients of the calendar months give an indication of stability or instability of price seasonality in the region. Tables II and III shows that the value of $\beta$ s are not equal to zero, therefore trend exist in the GSI series. Declining or negative trend coefficients is suggestive of decline in prices while positive trends shows that prices will continue to increase. Prices of dried ginger were negative for the months of January, February, June, July, November and December. This shows that marketing of dried ginger during these periods is less feasible as market glut might occur at these periods in the rural markets. Positive trends were obtained for the rest of the months, indicating that price of dried ginger will continue to increase and therefore producers and marketers should expect favorable returns on their investments.

In a similar way, the trend coefficient obtained in tomato showed that most of the months were negative except January and September. This is an indication that prices of tomato will continue to fall in the rural markets, consequently marketing of tomato in terms of better prices in these markets is less favorable.

Built on this inference it can be stated that there are price swings in production and marketing periods of dried ginger and tomato and that changes in price in the market is influenced by time variable. Therefore, marketers of tomato and dried ginger can enjoy better prices in urban markets than in rural markets where demand is very high. These results are in consonance with the findings of Akpan et al. (2014) who 
Creative commons User License: CC BY-NC-ND

Abstracted by: EBSCOhost, Electronic Journals Service (EJS),

Google Scholar, Journal Seek, Scientific Commons,

Food and Agricultural Organization (FAO), CABI and Scopus
Journal of Agricultural Extension

Vol. 22 (1) February, 2018

ISSN(e): 24086851; ISSN(Print); 1119944X

http://journal.aesonnigeria.org

http://www.aiol.info/index.php/iae

Email: editorinchief@aesonnigeria.org

ascertain that marketing of fresh tomato and pineapple in Akwa lbom State is generally not promising in terms of better prices at the rural levels.

\section{Gross Storage Returns (GSR)}

The GSI value was further used to determine the GSR of the commodity. Gross storage returns consider the seasonality in price changes which sellers can utilize to get better prices for their commodities. Gross storage returns are the nominal price margins within a season. The feasibility for storage was $20.71 \%$ and $21.44 \%$ for fresh tomato and dried ginger respectively. The result implies, that the producers/marketers of both tomato and ginger will make highest returns if they stored and sold to other (urban/international) markets during periods of high prices rather than selling at the rural market during harvests. Ngare et al. (2014) found a similar result in their study on the analysis of price volatility and implications for price stabilization policies in Mozambique.

\section{Conclusion and Recommendation}

The results revealed the existence of seasonality in the price series of both tomato and dried ginger in the market. The trend of the seasonal index of ginger was found to be generally negative in the rural markets indicating a declining trend caused by fewer incentives for the rural farmers and marketers of ginger. However, the trend of the seasonal index of tomato was generally positive which implied that tomato producers and traders enjoyed better prices than dried ginger traders. The variability of the Grand Seasonal Index was found to be high in general and this indicates that farmers and traders face high risk in producing and marketing of the crops. Nonetheless, tomato has a higher volatility than dried ginger in the market. The gross seasonal returns to storage were estimated to give the opportunities in time and space which farmers and traders of the crop could exploit. Based on the findings of this study, it can be concluded that seasonality is one of the major causes of variation in prices of both dried ginger and fresh tomato in the market. Therefore, to minimize the problem of price fluctuations and uncertainty at all levels of ginger and tomato marketing, the study recommends that farmers and traders should be provided with adequate information concerning prices, supply and demand especially at the local level. This will enable farmers and traders assess alternative opportunities of marketing their crops, and thereby minimizing the problem of low prices caused by seasonal glut.

\section{References}

Adenegan, K.O., \& Adeoye I.B. (2011). Price Analysis of Tomato in Rural and Urban Retail Markets of Oyo State. International Journal of Agricultural Economics and Rural Development, 4 (2), 261-277.

Adeoye, I.B., Odeleye, O.M.O., Babalola, S.O., \& Afolayan, S.O. (2009). Economic Analysis of Tomato Losses in Ibadan Metropolis, Oyo State, Nigeria. African Journal of Basic and Applied Sciences, 1, 87-92. 
Creative commons User License: CC BY-NC-ND

Abstracted by: EBSCOhost, Electronic Journals Service (EJS), Google Scholar, Journal Seek, Scientific Commons,

Food and Agricultural Organization (FAO), CABI and Scopus
Journal of Agricultural Extension

Vol. 22 (1) February, 2018

ISSN(e): 24086851; ISSN(Print); 1119944X

http://journal.aesonnigeria.org

http://www.ajol.info/index.php/jae

Email: editorinchief@aesonnigeria.org

Ajala M.K., Nwagu, B.I., \& Otchere, E.O. (2007). Socio-economics of Free Range Poultry Production among Agro-Pastoral Women in Giwa Local Government Area of Kaduna State, Nigeria. Nigerian Veterinary Journal, 28 (3), 11-18.

Akpan, S.B., Patrick, I.V., Edet G.E., \& John, D.E. (2014). Analysis of Price Transmission of Fresh Tomato and Pineapple in the Rural and Urban Markets of Akwa lbom Sate, Nigeria. American Journal of Agriculture and Forestry, 2 (3), 66-78.

Aminu, A. (2004). Marketing of Tomato and Onion in Jigawa state: A spatial and Seasonal Price Analysis. A dissertation in Agricultural Economics (Ph.D dissertation). Ahmadu Bello University, Zaria, Nigeria.

Aminu, A. (2006). Seasonality and Gross Real Returns to Storage of Onion Markets in Jigawa State. FAO corporate document repository. Food and Agricultural Organization of the United Nations. Retrieved August 20, 2017 from

ftp://ftp.fao.org/upload/Agrippa/690_en.doc.

Bhowmik, D., Kumar, K.P.S., Paswan. S., \& Srivastava, S. (2012). Tomato-A Natural Medicine and its Health Benefits. Journal of Pharmacognosy and Phytochemistry, 1(1), 33-43.

Busari, A.O., Idris-Adeniyi, K.M., \& Oyekale, J.O. (2012). Economic Analysis of Vegetable Production by Rural Women in Iwo zone of Osun State, Nigeria. Greener Journal of Agricultural Sciences, 3(1), 006-011.

El-Hori, A.I.S. \& Idris, B. (2011). Temporal Price Analysis of Wheat, Faba bean Dates and Garlic Crops in the Northern State, Sudan. Journal of Science and Technology, 12(03), 20-29.

Ewuziem, J.E., Onyenobi, V.O., Ironkwe, A.G. \& Tokula, M.H. (2015). Nigeria in World Ginger Trade: An Analysis of Performance from 2008 - 2012. Journal of Agriculture and Food Sciences, 13(2), 26-42.

Eze, J.I. \& Agbo, K.E. (2011). Comparative Studies of Sun and Solar Drying of Peeled and Unpeeled Ginger. American Journal of Scientific and Industrial Research, 2(2), 136143.

Food and Agricultural Organization (FAO) (2002). Ginger Post-Harvest Operations. FAO corporate document repository. Food and Agricultural Organization of the United Nations Retrieved on $20^{\text {th }}$ January from www.fao.org/3/a-av003e.pdf

Food and Agricultural Organization (FAO) (2011). Nigeria FAO STAT. Retrieved on $2^{\text {nd }}$ February from nso.nigeria.opendataforafrica.org/.../nigeria-fao-stat-water-resourcesagriculture-prod.

Folorunso, S.T. \& Adenuga K.M. (2013). An Analysis of Technical Efficiency of Ginger Crop Production in Jaba Local Government Area, Kaduna State, Nigeria. Advances in Applied Science Research, 4(5), 85-90. 
Creative commons User License: CC BY-NC-ND

Abstracted by: EBSCOhost, Electronic Journals Service (EJS),

Google Scholar, Journal Seek, Scientific Commons,

Food and Agricultural Organization (FAO), CABI and Scopus
Journal of Agricultural Extension

Vol. 22 (1) February, 2018

ISSN(e): 24086851; ISSN(Print); 1119944X

http://journal.aesonnigeria.org

http://www.ajol.info/index.php/jae

Email: editorinchief@aesonnigeria.org

Goetz, S. \& Weber, M.T. (1986). Fundamentals of Price Analysis in Developing Countries Food Systems: A Training Manual to Accompany the Microcomputer Software Program "MSTAT", Working Paper (29), Washington: Michigan State University.

Maddala, G.S., \& Kim, I.M. (1998). Unit roots, cointegration, and structural change (No. 4). Cambridge University Press.

Mathenge, M.K., \& Tschirley, D.L. (2006). Seasonal Analysis of Selected Fresh Fruit and Vegetable Prices at Wholesale Level in Key Urban Markets of Kenya (No. 55166). Michigan State University, Department of Agricultural, Food, and Resource Economics.

Ngare, L., Simtowe, F., \& Massingue, J. (2014). Analysis of Price Volatility and Implications for Price Stabilization Policies in Mozambique. European Journal of Business and Management, 6(22), 160-173.

Nmadu, J.N., \& Marcus, P.L. (2013). Efficiency of Ginger Production in Selected Local Government Areas of Kaduna state, Nigeria. International Journal of Food Agriculture and Economics, 1, 39-52.

NPC (2006). National Population Commission Census Report 2006.

Shende, N.V., \& Meshram, R.R. (2015). Cost benefit analysis and marketing of tomato. American International Journal of Research in Formal, Applied \& Natural Sciences, 1(11), 46-54.

Trotter, B. W. (1992). Applying Price Analysis to Marketing Systems: Methods and Examples from the Indonesian Rice Market (Vol. 3). Natural Resources Institute. 